\title{
Changes of Preservice Biology Teachers' Pedagogical Knowledge and Science Teaching Efficacy Belief through Science Pedagogy Course
}

\author{
Sun Young Kim* \\ Chosun University
}

\begin{abstract}
This study explored changes of preservice biology teachers' pedagogical knowledge and science teaching efficacy belief after the science pedagogy course. Preservice biology teachers who did not take any science pedagogy courses had an opportunity to engage in discussions of educational theories and group activities of instructional design utilizing science instructional models as a first step to develop practical knowledge. These preservice teachers represented a statistically significant increase in their scores on pedagogical knowledge including theory, student development, planning, and implementation, but no statistical difference in their scores measuring science teaching efficacy belief. In addition, the correlation results indicated that the science teaching efficacy belief is related to implementation even though the magnitude is relatively moderate.
\end{abstract}

Key words: preservice biology teacher, science pedagogy course, pedagogical knowledge, science teaching efficacy

\section{INTRODUCTION}

The reform movements in science education call for changes of teachers' practical knowledge emphasizing the importance of professional development as a means of achieving students' scientific literacy, a central goal of science education. Based on a constructivist view of learning, teachers need to identify students' prior conceptions, and then based on what students already know, teachers should be able to design an appropriate instructional setting (Glasersfeld, 1993; Howe \& Berv, 2000). Science teachers, hence, should be able to model an inquiry form of teaching leading to studentcentered learning (Radford, 1993; Supovitz \& Turner, 2000). In order to meet the current reform efforts that require more than traditional didactic science teaching, science pedagogy courses provided by teacher education programs are crucial for preservice teachers to eventually develop reform-based practical knowledge. Watters and Ginns (2000) maintain that preservice teacher education may be the most influential stage to achieve effective science teaching practices.
In order to achieve reform-based teaching, preservice teachers first need to obtain insights of notions of science teaching and learning. Learning educational theories such as constructivism may enable preservice teachers to be more comfortable in teaching science, which may enhance teaching practices in future (Hudson, 2005). In addition, Kemp et al. (1994) maintain that effective instructional design is based on understanding of educational theories. An instructional design process is a planning method that results in successful learning and performance (Kemp et al., 1994).

Hence, as a first step to develop notions of science teaching and learning for preservice science teachers who did not take any science pedagogy courses, this study provided opportunities of learning educational theories and science instructional models, and group activities of instructional design utilizing instructional models of science teaching. Then this study explored changes of preservice teachers' pedagogical knowledge and science teaching efficacy belief. Both pedagogical knowledge and science teaching self-efficacy are fundamental indicators of how prospective

${ }^{*}$ Corresponding author: Sun Young Kim (sykim519@chosun.ac.kr)

**Received on 15 February 2012, Accepted on 11 May 2012 
science teachers develop reform-based science teaching agendas. Pedagogical knowledge refers to teachers' knowledge of general pedagogy such as classroom management, questioning, planning, and so forth (Lederman \& GessNewsome, 1992). Teachers' self-efficacy beliefs are defined as the extent to which the teacher believes that he or she has ability to bring about positive student change. (Gibson \& Dembo, 1984). Cantrell, Young, and Moore (2003) maintain that a specific measure of science teaching efficacy beliefs may play a role as a predictor of future science teaching success of preservice teachers.

The primary purpose of this study is to track how these preservice teachers' pedagogical knowledge and science teaching efficacy belief change after their first science pedagogy course, and prepare adequate preservice teacher education programs based on their changes. Therefore, the research questions are as follows:

(a) How does preservice biology teachers' pedagogical knowledge change after their first science pedagogy course?

(b) How does preservice biology teachers' science teaching efficacy belief change after their first science pedagogy course?

(c) Is there a relationship between preservice biology teachers' pedagogical knowledge and science teaching efficacy belief?

\section{METHODOLOGY}

\section{Participants and Description of Course}

The preservice biology teachers $(\mathrm{n}=26 ; 7$ men, 19 women) with a mean age of 23 (ranging from 21-28) participated in this study. They were all enrolled in a science pedagogy course. Students were in their third year of college of education and had not taken any science pedagogy courses before.

Students had opportunities to learn about science instructional models and theories, and how to design lessons utilizing appropriate instructional models in the period of onesemester (three credit hours, 15 weeks). Figure 1 represents overall sequences of the science pedagogy course. During the phase 1 (week 1 to 3 ), preservice teachers learned educational theories and theorists such as Bruner, Ausubel, Vygotsky, Piaget, and so on. Then during the phase 2 (week 4-8), students learned and discussed on science instructional design models, such as cognitive conflict teaching model, generative learning teaching model, learning cycle teaching model, inquiry learning teaching model, STS teaching model, and so on. Then students had an opportunity of group activities of instructional design during the phage 3 (week 913). Two to three students who selected a same topic designed a lesson as a group according to a specific instructional model. Each group discussed possible students' misconceptions and identified instructional objectives. Then they brainstormed to select appropriate learning activities based on a selected model of science teaching. Finally, students reflected on educational theories and discussed instructional design processes during the phase 4 (week 14-15).

\section{Data collection and Analyses}

\section{Pedagogical Knowledge Instrument}

The instrument developed by Hudson and Ginns (2007) was translated and utilized for measuring preservice science teachers' pedagogical knowledge. The instrument is a five choice Likert-type scale with strongly disagree, disagree, uncertain, agree, and strongly agree as possible item responses. Four constructs were measured by this instrument: (1) understanding the theory for developing a science curriculum (construct: Theory) (e.g., articulate constructivist principles for teaching science); (2) understanding the development of students' concepts, abilities, skills, and attitudes (construct: Students' Development) (e.g., discuss the development of students' science concepts); (3) understanding effective planning for science teaching and 


\begin{tabular}{|c|l|}
\hline \multicolumn{2}{|c|}{ Phase 1 (week 1-3): Theories of Learning \& Theorists } \\
\hline Concepts & Constructivism, Piaget, Bruner, Ausubel, Vygotsky, etc. \\
\hline Activity & Discuss each theory \& reflect on conceptual change \\
\hline \multicolumn{2}{|c|}{$\downarrow$} \\
\hline Concepts & $\begin{array}{l}\text { Cognitive conflict teaching model, generative learning teaching model, } \\
\text { learning cycle teaching model, inquiry learning teaching model, STS } \\
\text { teaching model }\end{array}$ \\
\hline Activity & Discuss each stage of an instructional design model \\
\hline
\end{tabular}

\begin{tabular}{|c|l|}
\hline \multicolumn{2}{|c|}{ Phase 3 (week 9-13): Instructional Design } \\
\hline Concepts & $\begin{array}{l}\text { Key elements of the instructional design process; characteristics of learners, } \\
\text { objectives, teaching/learning activities, evaluation }\end{array}$ \\
\hline \multirow{3}{*}{ Activity } & $\begin{array}{l}\text { Group work of instructional design } \\
\text { - Select a content area for a specific instructional model } \\
\text { - Research students' misconceptions } \\
\text { - State instructional objectives } \\
- \text { Design activities according to each stage of an instructional design model } \\
- \text { Discuss each theory \& reflect on conceptual change }\end{array}$ \\
\hline
\end{tabular}

\section{$\downarrow$}

\begin{tabular}{|c|l|}
\hline \multicolumn{2}{|c|}{ Phase 4 (week 14-15): Reflection } \\
\hline Concepts & Advantage and disadvantage of each instructional design model \\
\hline Activity & $\begin{array}{l}\text { - Reflect on educational theories \& instructional models } \\
- \text { Discuss processes of instructional design }\end{array}$ \\
\hline
\end{tabular}

Fig. 1 Schematic of a science method course

learning (construct: Planning) (e.g., devise clear lesson structures) (4) implementing effective science teaching practices (construct: Implementation) (e.g., implement appropriate secondary science teaching strategies). In this study, the Cronbach's alpha values of each construct are $.751, .684, .676$, and .814 respectively (Table 1). The Dependent t-test was used to investigate how preservice teachers change their pedagogical knowledge through the science pedagogy course.

\section{Science Teaching Efficacy Belief Instrument (STEBI-B)}

Science Teaching Efficacy Belief Instrument (STEBI-B) was developed by Enochs and Riggs (1990) to measure preservice teacher confidence in teaching science. The STEBI B consists of two scales, the 13-item Personal Science Teaching Efficacy Belief (PSTEB) scale (e.g., I will continually find better ways to teach science), which assesses the belief that one's own teaching ability can be developed, and the 10-item Science Teaching Outcome Expectancy (STOE) scale (e.g., The teacher is generally responsible for the achievement of students in science), which assesses the belief that student's learning can be influenced by effective teaching (Enochs 
\& Riggs, 1990). Enochs and Riggs (1990) reported the Cronbach alpha coefficients of .90 and .76 respectively. In this study, the Cronbach alpha for both PSTEB and STOE was .79. Data were analyzed using the Dependent t-test whether preserivce teachers change their science teaching efficacy belief. In addition, Pearson correlation coefficient was used to examine the association among variables (e.g., theory, development, planning, implementation, PSTEB, and STOE).

\section{RESULTS AND DISCUSSION}

\section{Changes of Preservice Biology Teachers' Pedagogical Knowledge}

Compared to the pretest, students increased their scores of all four constructs (e.g., theory, students' development, planning, implementation) in the posttest, indicating the highest gain in the 'planning'. Table 1 shows the means and standard deviations of each construct. According to the t-test results, these score differences between the pretest and the posttest are statistically significant (see Table 2, 3, 4, \& 5).

\section{Theory for Developing Science Curriculum}

The construct 'theory' includes seven indicators (Table 2) measuring students' understanding of the theoretical underpinnings for developing science curriculum. As shown in Table 2 , the $t$-test result indicates the statistically significant increase in preservice science teachers' understanding of 'theory' compared to the pretest $(p<0.01)$. Among seven indicators, students developed good understandings on six indicators but did not demonstrate gains on the 'talking about science' (talk comfortably about teaching science) indicator. The lower scores in

Table 1

Descriptive Statistics and Cronbach's alpha for Four Construct of Pedagogical Knowledge

\begin{tabular}{|c|c|c|c|c|c|c|}
\hline \multirow{2}{*}{ Scale } & \multirow[t]{2}{*}{ Number of items } & \multicolumn{2}{|c|}{ Pretest $(n=26)$} & \multicolumn{2}{|c|}{ Posttest $(n=26)$} & \multirow{2}{*}{$\begin{array}{c}\text { Cronbach's } \\
\text { alpha }\end{array}$} \\
\hline & & $M$ & $S D$ & $M$ & $S D$ & \\
\hline Theory & 7 & 20.12 & 3.48 & 24.65 & 2.43 & .751 \\
\hline Students' development & 4 & 12.15 & 2.24 & 14.00 & 1.44 & .684 \\
\hline Planning & 10 & 30.58 & 4.02 & 35.00 & 2.90 & .676 \\
\hline Implementation & 12 & 48.04 & 5.22 & 52.38 & 4.53 & .814 \\
\hline
\end{tabular}

Table 2

Preservice Teachers' Pretest and Posttest Responses for the Construct "Theory"

\begin{tabular}{|c|c|c|c|c|c|c|c|c|c|}
\hline \multirow{2}{*}{ Indicator } & \multicolumn{3}{|c|}{ Pretest $(n=26)$} & \multicolumn{3}{|c|}{ Posttest $(\mathrm{n}=26)$} & \multirow[b]{2}{*}{$t$} & \multirow{2}{*}{$d f$} & \multirow[b]{2}{*}{$p$} \\
\hline & $M$ & $S D$ & $\%$ & $M$ & $S D$ & $\%$ & & & \\
\hline Syllabus & 2.77 & 0.77 & 10.70 & 3.62 & 0.50 & 57.10 & -5.897 & 25 & $.000 * *$ \\
\hline Rationale & 2.69 & 0.68 & 10.70 & 3.54 & 0.65 & 60.70 & -5.174 & 25 & $.000 * *$ \\
\hline Theory & 2.46 & 0.58 & 3.60 & 3.38 & 0.57 & 39.30 & -5.571 & 25 & $.000 * *$ \\
\hline Constructivist & 3.15 & 1.00 & 46.50 & 3.58 & 0.50 & 53.60 & -2.186 & 25 & $.038^{*}$ \\
\hline Teaching approaches & 2.92 & 0.80 & 25.00 & 3.65 & 0.56 & 64.30 & -4.792 & 25 & $.000 * *$ \\
\hline Viewpoints & 2.77 & 0.82 & 17.90 & 3.42 & 0.50 & 85.70 & -3.942 & 25 & $.001^{* *}$ \\
\hline Talking about science & 3.35 & 0.80 & 50.00 & 3.46 & 0.76 & 60.70 & -1.000 & 25 & .327 \\
\hline Total & 20.12 & 3.48 & $?$ & 24.65 & 3.62 & & -7.723 & 25 & $.000 * *$ \\
\hline
\end{tabular}

$\%$; Percentage of 'agree' or 'strongly agree'

$* p<.05 ; * * p<.01$ 
'talking about science' are reasonable in that students did not have any chance to teach science. Students represented the highest scores in 'theory' (provide a rationale based on theory for designing and implementing an effective science program), and next highest on both 'syllabus' (articulate the key components of the science syllabus) and 'rationale' (provide a rationale based on theory for designing and implementing an effective science program). In particular, about $86 \%$ of students in the posttest mentioned that they could articulate different viewpoints on teaching secondary science compared to $17.9 \%$ in the pretest (Table 2). The course intervention which emphasized various learning theories and instructional design models apparently helped students develop insights about different viewpoints on teaching science.

\section{Students' Development regarding to Concepts, Abilities, and Attitudes}

The comparison of the preservice teachers' scores on the construct, students' development, yielded a statistically significant increase compared to the pretest $(p<0.01)$ (Table 3$)$. While these preservice teachers represented a statistically significant increase in their scores on students' scientific reasoning ability, manipulative skills, and science concepts in the posttest (Table 3), no score difference occurs in 'attitude' (discuss the development of student's attitudes for learning secondary science). In addition, only one fourth of students responded that they could demonstrate an understanding of the students' development of manipulative skills for investigating science in the posttest even though scores showed a statistically significant improvement in the posttest (Table 3). Therefore, further program development which requires participants to do inquiry, practice questioning, and experimentation (Supovitz \& Turner, 2000) will be required to ensure more preservice teachers achieve these indicators.

\section{Effective Planning for Science Teaching and Learning}

Ten indicators measure the construct, 'planning'. As shown in Table 4, students significantly increased their overall scores of 'planning' in the posttest $(p<0.01)$. Notably, about $86 \%$ of students responded that they could select appropriate activities and resources for teaching science in the posttest, indicating about $29 \%$ increase of 'agree' and 'strongly agree' responses compared to the pretest (Table 4). This result indicates that the instructional intervention, especially designing lessons for a specific topic according to stages of each instructional model through discussion, helped students choose appropriate activities for teaching science. However, among ten indicators, three indicators (outcomes, integrate, and independent/collaborate) did not show any

\section{Table 3}

The Difference of Preservice Tachers' Pretest and Posttest Responses for the Construct 'Students' development"

\begin{tabular}{|c|c|c|c|c|c|c|c|c|c|}
\hline \multirow{2}{*}{ Indicator } & \multicolumn{3}{|c|}{ Pretest $(n=26)$} & \multicolumn{3}{|c|}{ Posttest $(n=26)$} & \multirow[b]{2}{*}{$t$} & \multirow[b]{2}{*}{$d f$} & \multirow[b]{2}{*}{$p$} \\
\hline & $M$ & $S D$ & $\%$ & $M$ & $\overline{S D}$ & $\%$ & & & \\
\hline Scientific reasoning & 2.73 & 0.67 & 10.70 & 3.42 & 0.58 & 46.40 & -4.797 & 25 & $.000 * *$ \\
\hline Attitude & 3.42 & 0.81 & 57.10 & 3.73 & 0.53 & 67.90 & -1.990 & 25 & .058 \\
\hline Manipulative skills & 2.73 & 0.78 & 10.70 & 3.19 & 0.57 & 25.00 & -2.601 & 25 & $.015^{*}$ \\
\hline Science concepts & 3.27 & 0.67 & 39.30 & 3.65 & 0.49 & 64.30 & -2.606 & 25 & $.015^{*}$ \\
\hline Total & 12.15 & 2.24 & & 14.00 & 1.44 & & -4.170 & 25 & $.000 * *$ \\
\hline
\end{tabular}

$\%$; Percentage of 'agree' or 'strongly agree'

${ }^{*} p<.05 ; * * p<.01$ 
Table 4

Preservice Teachers' Pretest and Posttest Responses for the Construct "Planning"

\begin{tabular}{|c|c|c|c|c|c|c|c|c|c|}
\hline \multirow{2}{*}{ Indicator } & \multicolumn{3}{|c|}{ Pretest $(n=26)$} & \multicolumn{3}{|c|}{ Posttest $(n=26)$} & \multirow[b]{2}{*}{$t$} & \multirow[b]{2}{*}{$d f$} & \multirow[b]{2}{*}{$p$} \\
\hline & $M$ & $S D$ & $\%$ & $M$ & $S D$ & $\%$ & & & \\
\hline Lesson plans & 2.92 & 0.74 & 21.40 & 3.42 & 0.50 & 39.30 & -2.687 & 25 & $.013^{*}$ \\
\hline Scope and sequence & 2.69 & 0.74 & 14.30 & 3.15 & 0.61 & 28.60 & -3.333 & 25 & $.003^{* *}$ \\
\hline Program & 2.77 & 0.77 & 21.40 & 3.46 & 0.51 & 46.40 & -4.215 & 25 & $.000 * *$ \\
\hline Outcomes & 2.88 & 1.03 & 25.00 & 3.23 & 0.65 & 32.10 & -1.32 & 25 & .195 \\
\hline Affective domain & 2.92 & 0.80 & 28.60 & 3.38 & 0.57 & 39.30 & -3.333 & 25 & $.003^{* *}$ \\
\hline Integrate & 3.42 & 0.90 & 53.60 & 3.62 & 0.64 & 50.00 & -1.154 & 25 & .259 \\
\hline Independent/collaborative & 3.27 & 0.78 & 46.50 & 3.62 & 0.50 & 57.10 & -1.979 & 25 & .059 \\
\hline Appropriate activities & 3.69 & 0.79 & 57.10 & 4.00 & 0.49 & 85.70 & -2.132 & 25 & $.043^{*}$ \\
\hline Inclusivity & 2.73 & 0.78 & 14.30 & 3.23 & 0.59 & 28.60 & -2.476 & 25 & $.020 *$ \\
\hline Concept map & 3.27 & 0.72 & 42.90 & 3.88 & 0.65 & 75.00 & -4.924 & 25 & $.000 * *$ \\
\hline Total & 30.58 & 4.02 & & 35.00 & 2.90 & & -5.513 & 25 & $.000 * *$ \\
\hline
\end{tabular}

$\%$; Percentage of 'agree' or 'strongly agree'

$* p<.05 ; * * p<.01$

statistically significant difference $(p>0.05)$. In this study, students worked only as a group when they designed instruction, and did not have many chances for cross-disciplinary integration. Therefore, further program development focusing on these constructs is needed for these preservice teachers.

\section{Implementing Science Teaching Practices}

The construct, 'implementation', measures preservice teachers' understanding of implementing effective science teaching practices. A total of 15 indicators are involved in this construct. According to the t-test results, students significantly increased their overall scores in the posttest $(p<0.01)$. Notably, about $68 \%$ of preservice teachers in the posttest mentioned that they could implement appropriate science teaching strategies. This represents an increase of 36\% in 'agree' and 'strongly agree' responses compared to the pretest. However, students did not show score gains in the indicator 'teaching confidently' compared to the pretest. Further, less than 30\% of preservice teachers agreed that they could teach secondary science with competent content knowledge (Table 5). Therefore, along with science pedagogy courses, programs that focus on subject matter knowledge are crucial in teacher education programs so that preservice teachers build their competence in content knowledge and deepen their content skills (Supovitz \& Turner, 2000).

\section{Changes of Preservice Biology Teachers' Science Teaching Efficacy Belief}

The Science Teaching Efficacy Belief Scales consists of two constructs, Personal Science Teaching Efficacy Belief (PSTEB) and Science Teaching Outcome Expectancy (STOE) (Enochs \& Riggs, 1990). The PSTEB means teachers' belief that they can successfully perform their teaching in effective ways, and the STOE is the belief that student learning can be influenced by effective teaching (Enchos \& Riggs, 1990). As shown in Table 6, the comparison of pretest and posttest scores did not show a statistical difference in science teaching efficacy scales scores for either PSTEB or STOE. Therefore, these results indicate that preservice science teachers did not gain enough confidence that they were capable 
Table 5

Preservice Teachers' Pretest and Posttest Responses for the Construct "Implementation"

\begin{tabular}{|c|c|c|c|c|c|c|c|c|c|}
\hline \multirow{2}{*}{ Indicator } & \multicolumn{3}{|c|}{ Preest $(n=26)$} & \multicolumn{3}{|c|}{ Posttest $(n=26)$} & \multirow[b]{2}{*}{$t$} & \multirow[b]{2}{*}{$d f$} & \multirow[b]{2}{*}{$p$} \\
\hline & $M$ & $S D$ & $\%$ & $M$ & $\overline{S D}$ & $\%$ & & & \\
\hline Problem-based learning & 3.31 & 0.93 & 42.80 & 3.65 & 0.69 & 64.30 & -1.735 & 25 & .095 \\
\hline Strategies & 3.00 & 0.80 & 32.10 & 3.77 & 0.51 & 67.90 & -5.130 & 25 & $.000 * *$ \\
\hline Classroom management & 3.50 & 0.58 & 53.60 & 3.65 & 0.56 & 67.20 & -1.000 & 25 & .327 \\
\hline Learning environment & 3.15 & 0.68 & 32.20 & 3.62 & 0.50 & 57.10 & -2.900 & 25 & $.008^{* *}$ \\
\hline Ethical issues & 3.81 & 0.75 & 75.00 & 4.08 & 0.27 & 96.40 & -1.895 & 25 & .070 \\
\hline Unit of work & 3.23 & 0.71 & 32.10 & 3.50 & 0.58 & 42.90 & -1.659 & 25 & .110 \\
\hline Assessments & 3.65 & 0.56 & 60.70 & 3.96 & 0.34 & 89.30 & -2.540 & 25 & $.018^{*}$ \\
\hline Critical reflection & 3.85 & 0.46 & 78.60 & 4.00 & 0.40 & 85.70 & -1.690 & 25 & .103 \\
\hline Questioning skills & 3.27 & 0.72 & 42.90 & 3.77 & 0.51 & 71.50 & -3.348 & 25 & $.003 * *$ \\
\hline Evaluate & 3.31 & 0.74 & 46.50 & 3.77 & 0.65 & 75.00 & -2.379 & 25 & $.025^{*}$ \\
\hline Hands-on lessons & 3.73 & 0.60 & 78.60 & 4.00 & 0.63 & 78.60 & -2.059 & 25 & .050 \\
\hline Content knowledge & 2.81 & 0.80 & 17.90 & 3.12 & 0.82 & 28.60 & -2.132 & 25 & $.043^{*}$ \\
\hline Teaching confidently & 3.46 & 0.81 & 57.20 & 3.46 & 0.71 & 57.10 & .000 & 25 & 1.000 \\
\hline Teach other countries & 2.58 & 0.81 & 7.40 & 2.65 & 1.09 & 18.50 & -.348 & 25 & .731 \\
\hline Positive attitudes & 3.96 & 0.66 & 55.00 & 4.04 & 0.45 & 79.30 & -.527 & 25 & .603 \\
\hline Total & 54.46 & 5.64 & & 59.08 & 5.04 & & -3.875 & 25 & $.001^{* *}$ \\
\hline
\end{tabular}

$\%$; Percentage of 'agree' or 'strongly agree'

$* p<.05 ; * * p<.01$

Table 6

Descriptive Statistics and t-test Results for Two Science Teaching Efficacy Belief Scales

\begin{tabular}{|c|c|c|c|c|c|c|c|c|}
\hline \multirow{2}{*}{ Scale } & \multirow{2}{*}{$\begin{array}{c}\text { Number of } \\
\text { items }\end{array}$} & \multicolumn{2}{|c|}{ Pretest } & \multicolumn{2}{|c|}{ Posttest } & \multirow{2}{*}{$t$} & \multirow{2}{*}{$d f$} & \multirow{2}{*}{$p$} \\
\hline & & $M$ & $S D$ & $\bar{M}$ & $S D$ & & & \\
\hline $\begin{array}{l}\text { Personal Science } \\
\text { Teaching Efficacy } \\
\text { Belief (PSTEB) }\end{array}$ & 13 & 44.96 & 4.82 & 45.92 & 3.45 & -.948 & 25 & .352 \\
\hline $\begin{array}{l}\text { Science Teaching } \\
\text { Outcome } \\
\text { Expectancy (STOE) }\end{array}$ & 10 & 34.81 & 3.37 & 34.54 & 3.68 & .412 & 25 & .684 \\
\hline
\end{tabular}

of teaching science in effective ways and that student learning could be influenced by their effective teaching. Since the class did not have any practical teaching experiences, this result supports that enhancing science teaching efficacy is closely related to actual teaching experiences as well as science teaching anxiety when they teach science (Czerniak \& Schriver, 1994; Deemer \& Minke, 1999). Microteaching experiences that preservice teachers present lessons to their peers would useful for preservice teachers in increasing science teaching efficacy (Son et al., 2007).

3. Relationship among Variables: Theory, Development, Planning, Implementation, PSTEB, and STOE

According to the Pearson product-moment correlation results (Table 7), the strongest 
Table 7

The Relationship among Variables: Theory, Development, Planning, Implementation, PSTEB and STOE

\begin{tabular}{lcccccc}
\hline \hline & Theory & Development & Planning & Implementation & PSTEB & STOE \\
\hline Theory & 1 & $.701^{* *}$ & $.609^{* *}$ & $.499^{* *}$ & .067 & -.199 \\
Development & & 1 & $.658^{* *}$ & $.607^{* *}$ & .177 & .088 \\
Planning & & & 1 & $.826^{* *}$ & $.457^{*}$ & .227 \\
Implementation & & & & 1 & $.559^{* *}$ & $.382^{*}$ \\
PSTEB & & & & 1 & .269 \\
STOE & & & & & 1 \\
\hline
\end{tabular}

** $p<0.01 ; * p<0.05$

relationship among variables is the relationship between 'planning' and 'implementation' $(r=.826, p<0.01)$, which indicates that 'planning' is strongly related to better understanding of 'implementation'. In addition, the relationships between 'theory' and 'development' ( $r=.701$, $p<0.01)$ as well as between 'theory' and 'planning' $(r=.609, p<0.01)$ imply that 'theory' may play an important role in both understanding of 'development' and 'planning'. Most importantly, the variable PSTEB is significantly associated with two variables, planning $(r=.457, p<0.05)$ and implementation $(r=.559, p<0.01)$, while the STOE is only significantly associated with implementation $(r=.382, p<0.05)$, although these correlation coefficients were relatively small (less than .60). This result indicates that even though science teaching efficacy is aligned with pedagogical knowledge (Khourey-Bowers \& Simonis, 2004; Park, 2006), pedagogical knowledge development is not sufficient to enhance science teaching efficacy. Further program development related to actual teaching experiences may be necessary to build science teaching efficacy.

\section{CONCLUSION AND IMPLICATION}

This study documented the processes toward preservice teachers' practical knowledge development though a science pedagogy course in which these preservice teachers' first learning about science teaching occurred. This study explored the changes of perservice biology teachers' pedagogical knowledge and science teaching efficacy belief after their first science pedagogy course. Preservice teachers, who did not take any previous science pedagogy courses, learned educational theories as well as various science instructional models, and were engaged in group activities of instructional design as a first step to develop a notion of science teaching. The results indicated that students developed overall understanding of pedagogical knowledge (e.g., theory, development, planning, implementation). This study, therefore, suggests that learning educational theories and having opportunities of instructional design along with a variety of science instructional models is effective in developing preservice science teachers' pedagogical knowledge. Science pedagogy courses provided by college of education plays a crucial role for preservice teachers to develop the fundamental qualifications.

However, students did not develop science teaching efficacy belief, both PSTEB and STOE. As this study revealed, both PSTEB and STOE are moderately related to the understanding of 'implementation'. Therefore, the failure in enhancing science teachers' teaching efficacy may result from their lack of experience of teaching science. Ginns and Watters (1999) maintain that successful science teaching experiences result in building teaching efficacy. Science education programs, hence, further prepare preservice teachers for having successful science teaching experiences in order to adequately build teaching efficacy (Ginns \& 
Watters, 1999). Their pedagogical knowledge developed through the science pedagogy course in this study would be a foundation for these preservice teachers to achieve high level of science teaching efficacy and perform successful teaching in future. Without understandings of pedagogical knowledge, preservice teachers could not develop science teaching efficacy, even though pedagogical knowledge alone is not sufficient to build teaching efficacy. As the importance of science education program has increased for preservice teachers' preparation (Sim, 2006), subsequent programs should be adequately developed and provided for these preservice teachers in order to successfully enhance science teaching efficacy based on pedagogical knowledge built up in this study.

\section{REFERENCES}

Cantrell, P., Young, S., \& Moore, A. (2003). Factors affecting science teaching efficacy of preservice elementary teachers. Journal of Science Teacher Education, 14(3), 177-192.

Czerniak, C. M., \& Schriver, M. L. (1994). An examination of preservice science teachers' beliefs and behaviors as related to self-efficacy. Journal of Science Teacher Education, 5(3), 7786.

Deemer, S. A., \& Minke, K. M. (1999). An investigation of the factor structure of the teacher efficacy scale. The Journal of Educational Research, 93(1), 3-10.

Enochs, L. G., \& Riggs, I. M. (1990). Further development of an elementary science teaching efficacy belief instrument: A preservice elementary scale. School Science \& Mathematics, 90, 694-706.

Gibson, S. \& Dembo, M. H. (1984). Teacher efficacy: A construct validation, Journal of Educational Psychology, 76(4), 569-582.

Ginns, I. S., \& Watters, J. J. (1999). Beginning elementary school teachers and the effective teaching of science. Journal of Science Teacher Education, 10(4), 287- 313.
Glasersfeld, E. (1993). Questions and answers about radical constructivism. In K. Tobin (Ed.), The practice of constructivism in science education (pp.23-38). New Jersey: Lawrence Erlbaum Associates.

Howe, K. R., \& Berv, J. (2000). Constructing constructivism, epistemology and pedagogy. In D. C. Phillops (Ed.), Constructivism in education: Opinions and second opinions on controversial issues (pp.19-40). Chicago,Illinois: The University of Chicago Press.

Hudson, P. (2005). Identifying mentoring practices for developing effective primary science teaching. International Journal of Science Education, 27, 1723-1739.

Hudson, P. \& Ginns, I. (2007). Developing an instrument to examine preservice teachers' pedagogical development. Journal of Science Teacher Education, 18, 885-899.

Kemp, J. E., Morrison, G. R., \& Ross, S. M. (1994). Designing effective instruction. New York: Macmillan College Publishing Company.

Kennedy, M. M. (1998). Education reform and subject matter knowledge. Journal of Research in Science Teaching, 35, 249-263.

Khourey-Browers, C., \& Simonis, D. G. (2004). Longitudinal study of middle grades chemistry professional development: Enhancement of personal science teaching selfefficacy and outcome expectancy. Journal of Science Teacher Education, 15(3), 175-195.

Lederman, N. G., \& Gess-Newsome, J. (1992). Do subject matter knowledge, pedagogical knowledge, and pedagogical content knowledge constitute the ideal gas law of science teaching? Journal of Science Teacher Education, 3(1), 1620.

Park, S. H. (2006). Pedagogical content knowledge among science teachers based on teaching method, self-efficacy, and attitude on science teaching. Journal of Korea Association of Research in Science Education, 26(1), 122-131.

Radford, D. L. (1993). Transferring theory into practice: A model for professional development for science education reform. 
Journal of Research in Science Teaching, 35(1), 7388.

Sim, J. (2006). Secondary school science teachers' perceptions about professionality and in-service training program for experiment. Korean Journal of Biology Education, 34(1), 2737.

Son, Y., Shin, J., Min, B. (2007). Analysis of pre-service biology teachers' class applying the science instructional model: Using the microteaching technique. Korean Journal of Biology Education, 35(3), 495-507.
Supovitz, J. A., \& Turner, H. M. (2000). The effects of professional development on science teaching practices and classroom culture. Journal of Research in Science Teaching, 37(9), 963-980.

Watters, J. J., \& Ginns, I. S. (2000). Developing motivation to teach elementary science: Effect of collaborative and authentic learning practices in preservice education. Journal of Science Teacher Education, 11, 301321. 